Revista Mídia e Cotidiano

Artigo Seção Temática

Número 8, março 2016

Submetido em: 29/01/2016

Aprovado em: 07/03/2016

\title{
NARRATIVAS DE MEMÓRIA E TERRITÓRIOS INVENTADOS: \\ A configuração das identidades e dos lugares como processos culturais
}

\section{MEMORY NARRATIVES AND IMAGINED TERRITORIES: Constructing identities and places as cultural process}

\author{
Ana Lúcia ENNE ${ }^{1}$; Marildo J. NERCOLINI²
}

Resumo: Neste artigo, abordamos algumas narrativas literárias de autores da América Latina para compreendermos como se articulam e enredam, através dessas ficções, as dimensões da memória, da identidade, da narrativa e da territorialidade. Buscamos demonstrar o quanto, na contemporaneidade, formas de narrar e representar as identidades associadas a territorialidades fluidas permitem a invenção de múltiplas formas de pertencimento, em contextos diaspóricos ou conflitantes, em que a memória funciona como elemento chave para as reconfigurações culturais do tempo e do espaço.

Palavras-chave: Memória; Identidade; Narrativa; Territorialidades; Pertencimentos.

Abstract: In this article, we will focus on some literary narratives from Latin American writers in order to understand how such fictional work articulate and seam issues of memory, identity, narrative and territoriality. We would like to demonstrate how modes of narration and representation associated with fluid territorialities are able to convey multiple forms of belonging, within diasporic or conflicted contexts, in which Memory acts as key element to reconfigure cultural senses of time and space.

Keywords: Memory; Identity; Narrative; Territoriality; Belonging.

\footnotetext{
${ }^{1}$ Professora do Departamento de Estudos Culturais e Mídia e do Programa de Pós-Graduação em Cultura e Territorialidades - PPCULT - UFF. anaenne@gmail.com

${ }^{2}$ Professor do Departamento de Estudos Culturais e Mídia e do Programa de Pós-Graduação em Cultura e Territorialidades - PPCULT - UFF. mjnercolini@gmail.com
} 


\section{míDiA \\ ecO DiAno}

\section{Introdução}

Em sua obra já clássica, Tempo e narrativa, Paul Ricoeur (1994) nos lembra que, na configuração narrativa, o autor introduz, para o leitor, o reino do "como se": como se o narrado fosse o mundo, como se fosse o passado, como se fosse o real, como se fosse aquele lugar, aquele tempo, aquelas pessoas, aqueles acontecimentos... $\mathrm{Na}$ tessitura narrativa, configuram-se as identidades e as alteridades, na espiral de pré-figurações, configurações e refigurações, nos lembrando que a memória nunca é pura ou estanque, sendo fundamentalmente elaboração e invenção no presente, a partir de estratégias discursivas, que possibilitam a construção de dimensões prospectivas para o mundo do receptor, visando a consolidação de efeitos de sentido. Narrar é, portanto, sempre ficcionar. Este é o ponto de partida de nosso artigo.

Se entendemos identidade como uma forma de narrativa de si e dos outros, podemos pensar, a partir das considerações de Michel Pollak (1992), que existe uma estreita relação, na construção das identidades, entre as dimensões do acontecimento, das pessoas/personagens e do lugar, o que nos remete diretamente à questão das territorialidades. Compreendemos, como diversos autores que exploraremos adiante, que os territórios, como formas de pertencimento aos lugares, são bem mais do que unidades físicas, são processos, relações de poder, redes simbólicas, elementos culturais. Como relações, envolvem territorialidades, jogos de construção e desconstrução. São, neste sentido, categorias discursivas, que envolvem esforço narrativo acerca da concepção dos lugares, que são fundamentais, como já indicamos, para configurar as identidades individuais e coletivas, sociais e culturais.

Partindo dessas premissas, nossa proposta é tomar como referência empírica algumas narrativas literárias de autores da América Latina para compreendermos como se articulam e enredam, através dessas ficções, as dimensões da memória, da identidade, da narrativa e da territorialidade. Intencionamos demonstrar o quanto as concepções acerca dos espaços e lugares, sejam eles associados aos recortes de nação, cidade, local ou global, dentre outras referências, são inventadas, no sentido narrativo do termo, operando dentro da proposta teórica e metodológica de Paul Ricoeur. Para isso, 


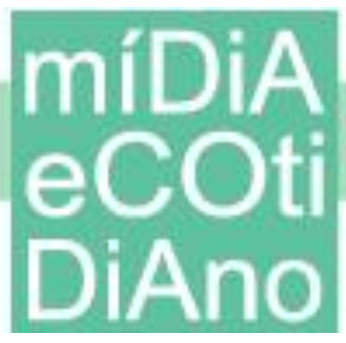

escolhemos, como corpus de análise, os romances/relatos: Meu país inventado, de Isabel Allende; Guia afetivo da periferia, de Marcus Faustini; Relatos de um certo oriente, de Milton Hatoum; e $O$ sol se põe em São Paulo, de Bernardo Carvalho. Todos têm um comum a construção, via narrativa, de identidades e territorialidades que são objetos de reflexão e tensionamentos. Podemos dizer acerca desses livros o mesmo que Carlos Heitor Cony afirmou sobre seu Quase memória: são um “quase-quase de um quase-romance de uma quase-memória” (CONY, 1995:7), misturando realidade e ficção, multivocalidade e fragmentação, territorialidades, desterritorialidades e reterritorializações, memórias, identidades e projetos, mosaicos e invenções, configurando uma narrativa que "oscila, desgovernada, entre a crônica, a reportagem e, até mesmo, a ficção", ou mais claramente, entre ficções e ficções e ficções.

Antes, porém, de nos voltarmos às análises propriamente ditas, apresentaremos algumas discussões preliminares sobre as categorias que as embasarão.

\section{Memória e identidade: algumas reflexões}

Maurice Halbwachs (1990) propôs o conceito de memória coletiva, definindo os quadros sociais que compõem esta memória. Para o autor, não existe memória puramente individual, posto que todo indivíduo está interagindo e sofrendo a ação da sociedade, através de suas diversas agências e instituições sociais. Além disso, toda memória é construída no presente, por agentes que visam sua reapropriação no futuro. As versões do passado, as diferentes abordagens históricas, as memórias coletivas que são acionadas pelos agentes sociais são reveladoras de preocupações encontradas no presente. É no presente, portanto, que a construção do passado é disputada como recurso para a construção de um futuro que responda às aspirações deste presente.

Estas possibilidades de apropriação do passado pela via do presente apontam para uma questão ainda maior: a construção de futuros possíveis. Assim, é no presente que a construção do passado é disputada como recurso para a construção de um futuro que responda às aspirações deste presente. García Canclini aponta para a necessidade de criar mitos e monumentos de preservação do passado como marcos fundamentais de construção de identidades, incluindo neste processo os documentos escritos. Na mesma linha de reflexão, Pierre Nora (1984) afirma que podemos perceber os museus, 


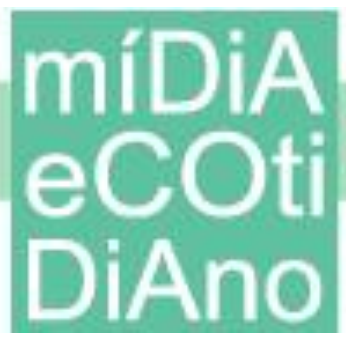

institutos históricos, casas de cultura, monumentos, textos literários, entre outros, como lugares de memória, cuja função é exatamente manter ativo o pertencimento a determinado vínculo identificatório. García Canclini afirma que "ter uma identidade seria, antes de mais nada, ter um país, uma cidade ou um bairro, uma entidade em que tudo o que é compartilhado pelos que habitam esse lugar se tornasse idêntico ou intercambiável”. E seria nesses territórios que "a identidade é posta em cena, celebrada nas festas e dramatizada também nos rituais cotidianos" (GARCÍA CANCLINI, 1998:190).

Há, como aponta Pollak (1992:204), um trabalho constante de "enquadramento da memória". É preciso escolher o que vai ser lembrado e o que deve ser esquecido, reiterando que "as preocupações do momento constituem um elemento de estruturação da memória". Como Halbwachs, Pollak insiste no aspecto de construção da memória como uma estratégia de agentes e agências sociais para ancorar identidades, pois há, segundo o autor, uma "ligação fenomenológica muito estreita entre a memória e o sentimento de identidade" (Id.,ibid.). Portanto, para Pollak, pensar a construção da memória só é possível quando relacionada diretamente ao tema da identidade; e, de acordo com esse mesmo autor, na construção da identidade, é preciso levar-se em conta três elementos essenciais: a unidade física (novamente remetemos à ideia de lugar, ou seja, à concepção espacial,); a continuidade dentro do tempo (não só no sentido físico, mas moral e psicológico, como frisa o autor); e, finalmente, "o sentimento de coerência, ou seja, de que os diferentes elementos que formam um indivíduo são efetivamente unificado." (Idem: 204).

Gilberto Velho vai acrescentar, às dimensões da memória e da identidade, a noção de projeto, tomando por base a definição de Alfred Schutz como uma "conduta organizada para atingir finalidades específicas" (VELHO, 1994:101). Assim, como explica Velho, "se a memória permite uma visão retrospectiva mais ou menos organizada de uma trajetória e biografia, o projeto é a antecipação no futuro dessas trajetória e biografia, na medida em que busca, através do estabelecimento de objetivos e fins, a organização dos meios através dos quais esses poderão ser atingidos” (Id., ibid.). 
Dessa forma, não podemos pensar a construção da identidade como algo puramente individual ou coletivo, mas como uma permanente negociação entre indivíduo e sociedade. E, principalmente, não podemos tomar tal construção como algo estático ou pronto, mas entendê-la como um processo permanente de interação e fluxos. Ou seja, não podemos falar, quando pensamos em tal processo de construção, de uma só identidade social, mas sim na configuração de múltiplas identidades, por vezes convergentes, em outras divergentes, mas sempre fluidas e movendo-se a partir de fronteiras interativas.

Por outro lado, pensar o conceito de identidade pressupõe pensar em sua relação com alteridade, pois trata-se de um conceito que necessita do outro para ser referendado, ou seja, não se constrói identidade para si e por si, é preciso interagir para que ela faça sentido. Tomaz Tadeu da Silva (2000) enfatiza que a identidade se constrói em uma relação dialógica e de interdependência com a diferença. Não basta constatar e celebrar a identidade e a diferença, naturalizando-as. É necessário vê-las como uma construção que se dá no que ele chama de processo de diferenciação, problematizando e colocando em questão como elas são produzidas socialmente, os contextos, os agentes que entram nessa disputa por demarcar as fronteiras entre "nós" e os "outros", entre o considerado "normal" e o "desviante". Portanto, como também vai nos afirmar Stuart Hall, as identidades (e portanto as diferenças) são formadas culturalmente, são construídas no interior das representações, nos embates culturais, e não fora deles; são resultados de um processo que permitem que nos "posicionemos no interior das definições que os discursos culturais (exteriores) fornecem ou que nos subjetivemos (dentro deles)" (HALL, 1997: 27); são construções, portanto, discursivas e dialógicas.

\section{Identidades e questões de espaço, lugar e território}

A luta pela memória e, portanto, pela configuração das identidades, é uma disputa pela narrativa e pelo discurso, em suma, pela posse da palavra. Neste sentido, o trabalho de Pierre Bourdieu revela-se fundamental. O autor nos lembra o quanto as espacialidades são criadas a partir de discursos performativos, em que o poder do enunciador, sua autoridade discursiva, delimita as fronteiras e nomeia os espaços (BOURDIEU, 1989). Em outro trabalho, Bourdieu (2007) indica que é impossível 


\section{míDiA \\ ecO DiAno}

separar a representação do real do próprio real, o que implica em compreendermos a dimensão social do espaço como correlata à sua dimensão física, pois os diversos atributos de capital asseguram aos sujeitos formas distintas de ocupar e significar os territórios.

Se entendemos que a construção de identidades, via memória, permite situar os agentes dentro de espaços simbólicos e físicos, alguns conceitos se apresentam como fundamentais, entre eles os de lugar, espaço e território. Antes de tudo, precisamos pensar de que forma uma mesma área pode ser construída de forma múltipla a partir das diferentes referências dos agentes sociais, da mesma forma que pensamos as identidades como construídas em perspectivas inter-relacionais.

De certa maneira, estamos lidando com operações de negociação onde os agentes sociais estão buscando se apoderar de determinada noção que corresponde a uma abordagem espacial. Neste sentido, podemos nos remeter à raiz etimológica, por exemplo, da categoria de região, que tem em regio sua sustentação (BOURDIEU, 1989). É importante reparar que o radical reg também funda palavras como regente, regina (rainha) e regência, todas palavras que remetem à domínio e a poder. Trata-se de se apoderar de um domínio, de um território a ser construído cotidianamente. Portanto, uma das questões centrais, no que se refere à noção de território, é sua associação com a esfera do poder. Mas é preciso ir além nessa discussão.

Marcelo Souza (1995: 84) procura demonstrar de que forma o conceito de território - à maneira de região - sofreu transformações em seu desenvolvimento histórico. Assim, território primeiramente era pensado como "espaço concreto em si (com seus atributos naturais e socialmente construídos) que é apropriado, ocupado por um grupo social". Para o autor, o senso comum - reiterado por alguns pensadores, especialmente os ligados à Geografia Política - tende a relacionar território com Estado, o que empobreceria o conceito. Para Souza (Id., ibid.: 87),

Territórios, que são no fundo antes relações sociais projetadas no espaço que espaços concretos (os quais são apenas os substratos materiais das territorialidades) (...), podem (...) formar-se e dissolver-se, constituir-se e dissipar-se de modo relativamente rápido (ao invés de uma escala temporal de séculos ou décadas, podem ser simplesmente anos ou mesmo meses, semanas ou dias), ser antes instáveis que estáveis ou, mesmo, ter existência 
regular mas apenas periódica, ou seja, em alguns momentos - e isto apesar de que o substrato espacial permanece ou pode permanecer o mesmo.

Esta noção de território aponta para territorialidades flexíveis, flutuantes e móveis. Para esse mesmo autor, é impossível pensar a noção de território em sociedades urbanas complexas sem pensar, conjuntamente, a noção de redes sociais. $\mathrm{O}$ autor propõe que se trabalhe com territorialidades superpostas, que permitam perceber como os atores em suas redes sociais constroem e descontroem seus territórios, estabelecendo relações de poder e domínio que de fato implicam em significados diversos. Conforme afirmam Haesbaert e Limonad (2007:42), “o território não deve ser confundido com a simples materialidade do espaço socialmente construído, nem com um conjunto de forças mediadas por esta materialidade", pois o território "é sempre, e concomitantemente, apropriação (num sentido mais simbólico) e domínio (num enfoque mais concreto, político-econômico) de um espaço socialmente partilhado."

Neste sentido, a noção de territorialidade seria mais rica do que a de território, pois:

[...] a territorialidade, além de incorporar uma dimensão estritamente política, diz respeito também às relações econômicas e culturais, pois está "intimamente ligada ao modo como as pessoas utilizam a terra, como elas próprias se organizam no espaço e como elas dão significado ao lugar" (SACK apud HAESBAERT, 2004:3).

Podemos pensar a relação da territorialidade com as apropriações do espaço, configurando lugares, no sentido cultural. Uma interpretação proposta por Asa Briggs nos permite trabalhar com a possibilidade da construção social da categoria de lugar. Para o autor, é preciso distinguir espaço de lugar, em que "espaço é transformado em lugar quando ele adquire definição e significado" (BRIGGS, 1985:87). Assim, o lugar é sempre resultado da experiência sobre o espaço. Ele considera essencial reiterar que "cidades são coleções de lugares tanto quanto lugares em si" (Id.: 90). Ao analisar algumas representações verbais e imagéticas acerca de lugares, Briggs aponta para o caráter polissêmico das mesmas. Lugares não são uma categoria estática, mas o resultado de fluxos e interpretações diversas, são carregados de interpretação, sendo, portanto, construídos socialmente, e não simplesmente espaços geograficamente dados. A semantização do espaço, dessa forma, cria os múltiplos sentidos para o que o autor 


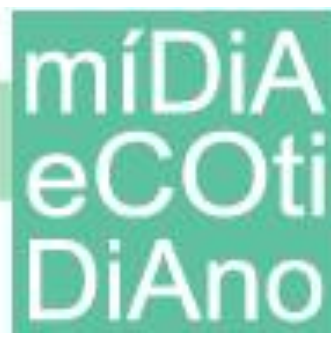

chama de lugares, e, exatamente por isso, "quando nós falamos sobre lugares, nós falamos sobre vida..." (Id., ibid.: 103).

Partindo das concepções desses autores, pressupomos que os espaços narrados nos romances/relatos que escolhemos analisar não são, portanto, somente espaços físicos, embora também o sejam, mas, antes de tudo, espaços sociais, lugares socialmente experimentados pelos diversos agentes que são vocalizados nas narrativas, incluindo o autor e seus personagens, territorialidades múltiplas que se interpenetram, contrastam, dialogam, negociam. Tomando por base essas considerações teóricas, pretendemos discutir esses pontos a partir dos livros selecionados, como demonstraremos a seguir.

\section{Um país inventado - lições do exílio}

A chilena Isabel Allende, em razão do golpe de Estado que vitimou seu tio Salvador Allende, presidente da República, em 1973, assim como muitos de seus conterrâneos, foi obrigada a viver exilada de seu país. Acabou se fixando nos Estados Unidos, inclusive se casando com um norte-americano e lá constituindo família. Por muito tempo, como ela mesma narra, sua história acabou se ligando mais fortemente à sua casa nos EUA, aos hábitos de seu marido e aos traços culturais do país que a acolheu. No entanto, sua relação afetiva com o Chile sempre se manteve forte, mesmo com a distância a que foi submetida. E esses laços amorosos, familiares, extremamente viscerais, foram reconstruídos, através de jogos memorialísticos e ficcionais, em seus diversos romances, como A Casa dos Espíritos, De amor e de sombras, Paula e, especialmente, em Meu país inventado, sobre o qual nos debruçaremos aqui.

Neste relato autobiográfico, Isabel Allende descreve o Chile como aprisionado em sua memória, o "seu" Chile. E em diversos momentos exercita a meta reflexão acerca do fazer da escrita, da construção via memória de uma identidade nacional, do quanto aquilo que se entende por um país, uma dimensão territorial, um espaço delimitado, está atravessado pela imaginação e pela criação inventiva.

Assim, por exemplo, em determinado trecho do livro, ela coloca em dúvida as lembranças mais singelas, acerca, por exemplo, da sua avó "mística" que movia o açucareiro sem tocar nele: 
Não sei se alguma vez assisti a essa proeza ou se de tanto ouvir falar a seu respeito acabei convencida de que foi verdadeira. Não me lembro do açucareiro, mas parece-me que havia uma campainha de prata (...). Não sei se sonhei com o seguinte episódio, se o inventei ou se fato aconteceu (...). Essa lembrança vem juntamente com a de outros eventos e casos de minha existência que me parecem realmente vividos, mas tornam-se um tanto improváveis quando os levo para o papel e os confrontos com a lógica. Esse problema, porém, não me inquieta. Que importa se realmente ocorreram ou se os imaginei? De qualquer modo, a vida é sonho (ALLENDE, 2003:92).

Imaginar eventos familiares, inventar um país. Não importa, para a autora, a grandeza do descrito, o que interessa é, na configuração de sua narrativa, dar voz e vida à família, aos amigos, às cidades, ao Chile vivenciado ou sonhado. A narrativa nem sempre é amorosa. Em alguns trechos, ela descreve o Chile "como um país hipócrita, pudibundo e repleto de escrúpulos em relação à sensualidade" (Idem,162); ao mesmo tempo, diz ela, os chilenos são gentis, amam falar de política, se incomodam com a aparência e não gostam de falar que são felizes. Revelando seu desejo de se apropriar daquele território, sem, contudo, para ele voltar, a autora afirma:

No meu caso não é tanto o desejo de viver no Chile, mas o de recuperar a segurança com que ali me movimento. Aquele é o meu chão. Cada povo tem seus costumes, manias, complexos. Conheço, como a palma da mão, as idiossincrasias do meu, nada me surpreende, posso antecipar as reações dos demais, entendo o que significam seus gestos, os silêncios, as frases de cortesia, as reações ambíguas. Só ali me sinto socialmente acomodada (...). (Id., ibid.:165)

Há, no trecho acima, uma declaração de pertencimento e reconhecimento. No entanto, mesmo afirmando conhecer as idiossincrasias de seu povo "como a palma da mão", Isabel Allende reconhece, em diversos momentos da narrativa, o quanto o "seu" Chile é inventado, uma construção no presente, instante cravado pela configuração de seu texto, a partir de suas vivências e nostalgias, que provavelmente não encontra eco no "verdadeiro" Chile.

Tenho uma imagem romântica de um Chile congelado no começo da década de 70. Durante anos acreditei que quando a democracia voltasse tudo seria como antes, mas mesmo essa imagem congelada era ilusória. Talvez o lugar de que me sinto saudosa jamais tenha existido (...). Construí a ideia de meu país como um quebra-cabeças, selecionando as peças ajustáveis ao meu desenho e ignorando as demais. Meu Chile é poético e pobretão; por isso descarto as evidências dessa sociedade moderna e materialista (...), e insisto 
em ver por toda a parte os sinais do meu país de antigamente (Id., ibid.: 215216).

As estratégias memoráveis estão lá: recortes e escolhas, seleção de "peças ajustáveis, ignorando as demais". Trabalhos de enquadramento, seleção, acomodação, silenciamento, de que fala Maurice Halbwachs (1994). A partir desses trabalhos, a autora constrói o Chile de sua nostalgia, mais próximo ao que teria vivido em sua infância e juventude, antes do exílio, mas desconfia que mesmo esse já seria "inventado", sentindo-se saudosa de um lugar "que [talvez] jamais tenha existido". Nesse processo de construções e desconstruções, Allende busca se localizar, construir-se enquanto diaspórica, vivenciando os entre-lugares de estar longe da pátria, mas não esquecer seus traços culturais. Assim, ela afirma: "criei também uma versão de mim mesma sem nacionalidade, ou, melhor, com múltiplas nacionalidades. Não pertenço a um território, mas a vários, ou talvez só pertença ao âmbito a ficção que escrevo" (Id.: 216).

Desterritorializada, a escritora se reconstrói e reconfigura seus territórios de existir, através dos usos e abusos da ficção. Mesmo refletindo em muitos trechos sobre isso, não dicotomiza sua narrativa entre real e invenção, propondo uma leitura dialética e complexa do mundo e da narrativa sobre ele:

\footnotetext{
Não pretendo saber o quanto da minha memória são fatos verdadeiros e o quanto foi inventado por mim, pois não me cabe a obrigação de traçar a linha entre uma coisa e a outra. Andrea, minha neta, escreveu uma composição escolar na qual declara: "Gosto da imaginação da minha avó", Perguntei-lhe a que se referia e ela replicou sem vacilar: "você se lembra das coisas que nunca aconteceram". Mas não fazemos todos o mesmo? Dizem que o processo cerebral de imaginar e o de recordar parecem tanto que são quase inseparáveis. Quem pode definir a realidade? (Id., ibid.: 216)
}

Isabel Allende inventou um país através de suas reminiscências. Marcus Faustini, através de processos narrativos também fragmentados, inventou não só uma cidade, mas uma metodologia de percurso, como veremos a seguir.

\section{Um percurso de cidade inventado - deslocamentos e apropriações}

No caso descrito acima, uma escritora exilada precisa, via memória, reinventar seu país e conferir sentido ao território que um dia lhe pertenceu. Trata-se, neste sentido, 
de uma reapropriação, de uma forma imaginária de reconquistar o perdido, de reconfigurar o experimentado, de reconhecer-se naqueles espaços, sujeitos, traços e acontecimentos. Agora, vamos nos debruçar sobre o relato de Marcus Faustini, que precisa operar seus agenciamentos sobre um não próprio, sobre lugares que poderiam ser pensados, seguindo a linha reflexiva de Marc Augé (2012), como não lugares (como vagões de trem, calçadas, estações rodoviárias, esquinas etc.), ou como interditos, lugares hostis a ele, menino de periferia que cruzava a cidade para estudar, trabalhar, consumir... No entanto, em seu livro Guia Afetivo da Periferia, Faustini apresenta uma lista rica de astúcias, de formas de apropriação, de modos de fazer com, no sentido proposto por Certeau (1998), de todos esses lugares e não lugares, ressignificando o espaço, constituindo múltiplas territorialidades e temporalidades. Dessa forma, ao descrever seus recursos para lidar com os percursos, Faustini inventa a cidade e confere a ela sentidos novos, em uma poética pirata e valente, como podemos perceber nos trechos selecionados.

Durante os três anos do meu curso noturno de teatro, experimentei várias estratégias para chegar em casa, inclusive dormir a rua ou no banco de espera do Hospital Souza Aguiar. Conseguir chegar à rodoviária de Campo Grande e, de lá, pegar o 839 - Campo Grande/Cezarão - era a minha meta durante as noites de segunda a sexta (FAUSTINI, 2009: 31)

Como a viagem do centro de Santa Cruz até o centro do Rio se tornou por diversas razões cotidiana, comecei a criar procedimentos que me fizessem esquecer como era longa. Quando fazia o trajeto de trem, dividia a viagem em duas partes para não ser tomado pelo tédio da repetição. (...) Na espera do trem, observava as pessoas e criava pequenas histórias de cada uma. Era meu território particular de invenção. (Id., ibid.: 37-38)

Para garantir a minha circulação pela cidade, criei uma economia muito particular. Uma estratégia simples. Quando tinha emprego ou trabalho, investia tudo em livros e discos. (...) Desempregado ou sem trabalho, percorria essa mesma geografia vendendo essas mesmas mercadorias, por um preço significativamente inferior. (...) Assim, passei a mapear o centro do Rio de Janeiro de acordo com as minhas possibilidades de sobrevivência. (Id., ibid.: 51-54)

Criatividade e imaginação. Através desses recursos, Faustini fazia da cidade, em suas múltiplas territorialidades, seu "território particular de invenção". Ele nos conta: "Assim, eu olhava o mapa dos bairros do Rio de Janeiro exposto na banca e ia renomeando a cidade. Santa Cruz passei a chamar de um mar de possibilidades e 


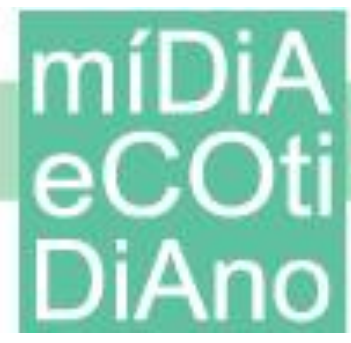

Ipanema, de talvez" (Id.: 69). Transformando o percurso em aprendizagem, reconfigurou em suas andanças as cartografias do afeto, do desejo, das subjetividades. Combinando táticas e estratégias, foi se apoderando da cidade, se apropriando de espaços que, por cortes de classe, por exemplo, pareciam não destinados a meninos que tinham a mesma origem social.

Todo meu aprendizado está nesse percurso. Tudo o que está localizado entre Santa Cruz e Ipanema. Sentado no meio-fio, esperando a van de madrugada, vendo o mar bravio como o que engoliu Escobar, eis a Ipanema que se repetiu durante anos para mim. (...) Nunca tive coragem de frequentar Ipanema durante o dia, mas me sentia em casa sentado no meio-fio esperando a van para Santa Cruz. (Id., ibid.: 39-44)

O percurso, neste sentido, era tão importante quanto os pontos de partida e de chegada. Porque o deslocamento permitia os jogos de apropriação, a construção das metáforas, no sentido indicado por Certeau (1998), produção simbólica dos espaços transformados em lugares, se não próprios em termos de capital econômico, apropriados pelo capital cultural e discursivo. Assim, "o destino da sexta à noite não era apenas o que estava em jogo. O trajeto também fazia parte da experiência" (FAUSTINI, 2009:48).

Se o percurso era estrategicamente utilizado como forma de se apropriar dos espaços, a narrativa do relato autobiográfico pode ser compreendida, também, como uma espécie de trajeto entre aquele rapaz de poucos recursos que criativamente exercia sua poética de cidade e o produtor cultural consagrado, responsável por uma instituição voltada para agência de jovens na cidade do Rio de Janeiro, que em diversas falas públicas, artigos e no livro aqui analisado, inscreve suas invenções como uma ação efetiva no espaço, mas uma metodologia no tempo, que, de certa forma, se pretende reconfigurada nas apropriações também dos leitores, principalmente de jovens que, como ele, precisam lutar e construir estratégias de ocupação territorial em um ambiente urbano que, muitas vezes, segrega e estigmatiza o jovem de baixa renda, morador das periferias urbanas. Neste sentido, a narrativa de Faustini tem uma dimensão claramente memorialística, mas deve ser compreendida em sua dimensão prospectiva, como um projeto, construído no presente da tessitura do relato, pedagógico, de como é possível se apropriar taticamente da cidade, inventá-la e reconfigurá-la, o que deveria ser direito de 


\section{eco DiAno}

todo cidadão. Os trechos abaixo nos ajudam a entender essa dimensão pedagógica e projetiva do relato:

Caminho por todo o centro da cidade (...) até chegar ao Palácio Gustavo Capanema. Gosto de cruzar aqueles pilotis e sentir o vento batendo na cara. É tão bom como pedir um guaraná Convenção e um cachorro-quente na Praça do Curral Falso, em Santa Cruz. (...) Quando exausto, sento encostado no pilotis e espero o tempo passar. Ali é meu lugar no centro do Rio de Janeiro. Todo carioca deveria ter direito a um lote imaginário no centro da cidade, onde seria o lugar mais apropriado para pensarmos no sentido de ser carioca. (Id., ibid.: 66).

Na cidade, eu procuro a ficção. Não se trata de inventar histórias, nem de negar-se ao mundo, aos objetos e às relações formativas desta civilização carioca. Trata-se de fruir, de buscar ao longo do dia o direito a esse instante. (Id., ibid.: 74)

Ficcionar é, portanto, uma forma de ocupar e se apropriar do espaço urbano, de territorializá-lo, de criar pertencimentos e fruições. Não como uma concessão, mas como um direito, pois "ficar na esquina é tão importante quanto ter um quarto" (Id.:105). Nos fragmentos de memória do autor, é possível perceber os efeitos de sentido pretendidos, a busca da realização da tríplice mimese de Ricoeur, devolvendo, ao leitor, o mundo da prefiguração, mas já mediado pelas experiências e percursos do autor, que, assim, pretende reconfigurar não só a forma de leitura de seu receptor, mas também os modos deste percorrer e consumir a cidade. Neste sentido, há uma dimensão política em sua narrativa, um projeto performativo de transformar uma pedagogia subjetiva do espaço em experiência partilhada e reconfigurada em "lotes imaginários", em uma reforma simbólica dos latifúndios culturais que marcam os espaços das grandes cidades.

\section{Cidades-mundo inventadas - territórios de criações e recriações identitárias}

Cresce em importância o papel da cidade, sobretudo das megalópoles globalizadas, como local apropriado para viver a cultura resultante do diálogo e dos embates entre as várias culturas que nela se fazem presente. A cidade-mundo se transforma no principal espaço de interação entre as forças globais e as culturas locais; nela se negocia a circulação em escala global de pessoas, de bens e tecnologias, de ideias, imagens e produtos culturais. No dizer de Bhabha, a cidade transforma-se no 


\title{
míDiA

espaço de "disseminação", em que se reúnem povos dispersos, com seus mitos, fantasias e experiências:

\begin{abstract}
Essas geografias imaginativas que abarcaram países e impérios estão mudando; aquelas comunidades imaginadas que atuavam nos limites uníssonos da nação estão cantando com vozes diferentes. Se comecei com a dispersão do povo através dos países, quero terminar com sua reunião na cidade. (...) É para a cidade que os migrantes, as minorias e os diaspóricos vêm para mudar a história da nação. (...) É a cidade que oferece o espaço no qual identificações emergenciais e novos movimentos sociais do povo são encenados (BHABHA, 1998: 237).
\end{abstract}

A possibilidade da intensificação do entrelaçamento de culturas, em uma época em que tempo e espaço se reconfiguram frente às novas possibilidades tecnológicas e as intensas migrações, possibilita a intensificação do contato com o diverso, acarretando transformações individuais, grupais e societais também intensas. Para Monsivais (2000), o século XX marcou-se por ser uma época de intensas migrações, destacando as culturais, pois,

(...) estas migraciones han sido a tal punto radicales que, en distintos períodos, inventan o legitiman (corroen o rectifican) apariencias urbanas, jerarquías y comportamientos familiares, estilos del consumo, escuelas del sentimiento y el sentimentalismo, idolatrías frenéticas que, las más de las veces, nadie recuerda a los cinco años de su apogeo" (MONSIVAIS, 2000: 33).

Os "migrantes culturais" - expressão usada pelo autor - provocam profundas modificações socioculturais, adotando atitudes e costumes diversos daqueles com os quais foram educados. Eles colocam em questão, abandonam ou modificam devoções, gostos, maneiras de usar o tempo livre, convicções religiosas e estéticas... enfim, propiciam processos transculturais. Cabe ressaltar que vivemos um tempo em que essa transculturalidade é feita de maneira cada vez mais acentuada e intensa pelos meios midiáticos e virtuais, afinal hoje é possível "marchar hacia ninguna parte, con la condición de que el viaje lleve a todos lados" ((Id., ibid.: 33).

Os fenômenos culturais, como hoje se apresentam, para serem compreendidos necessitam de análises que superem os estudos centrados nas culturas meramente locais, tradicionais e estáveis; precisam levar em conta os processos translocais e o papel profundamente ativo que a imaginação social tem nesse contexto. $\mathrm{O}$ imaginário passa a 


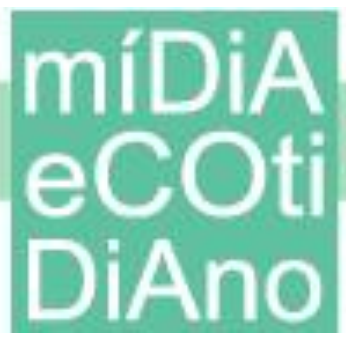

ter um papel-chave no jogo cultural. É um imaginário alimentado não somente pelo campo do possível dado pelo espaço em que se vive, mas pelas possibilidades trazidas pelo outro, pelas outras culturas, conformando-se num imaginário intercultural que perpassa distintas sociedades, que entra no jogo da criação e recriação de territórios, trazida sobretudo pelos migrantes, pelos sujeitos diaspóricos, pelos nativos que se apropriam das novas tecnologias da informação, pela mídia.

É importante não esquecer, no entanto, que a globalização da cultura não significa sua homogeneização. Se, por um lado, a globalização inclui a utilização de uma variedade de instrumentos de homogeneização (armamentos, técnicas publicitárias, hegemonias linguísticas, modas e estilos de roupa), que são absorvidos nas economias políticas e culturais locais, por outro, ela é um processo profundamente histórico e, como afirma Appadurai (2001), gerador de localidades, na medida que as diferentes sociedades e grupos humanos se apropriam de maneira distinta dos materiais disponíveis, recriam-nos a partir de suas tradições, de suas necessidades e desejos.

A atual política cultural global é de uma ordem complexa, deslocada e repleta de justaposições, decorrente das deslocações entre economia, cultura e política. Appadurai propõe uma análise em torno de cinco dimensões que, por serem irregulares e fluidas, denomina paisagens. As relações estabelecidas entre as cinco diferentes paisagens (a saber: paisagem étnica; paisagem tecnológica; paisagem financeira; paisagem midiática; e paisagens ideológicas) expressam as inflexões provocadas pela situação histórica, linguística e política das distintas classes de atores envolvidos:

Estado-nação, corporações multinacionais, comunidades em diáspora, grupos e movimentos contidos dentro de cada nação (de índole religiosa, política ou econômica) e até pequenos grupos caracterizados pela natureza íntima e uma forma de relacionar-se cara a cara (...) (APPADURAI, 2001: 47).

Tais paisagens dão os fundamentos dos fluxos da atualidade. Sempre houve o deslocamento e o fluxo de pessoas, capital financeiro, imagens, máquinas e ideias no decorrer da história, mas não com a velocidade, na escala e nos volumes que atualmente se dão, esses processos, hoje, são centrais para se pensar a construção das identidades, da memória, das distintas territorialidades, fundamentais, portanto, para se pensar como hoje vivemos e nos situamos no momento contemporâneo. 


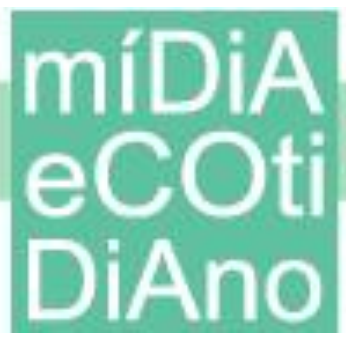

A literatura contemporânea, criada no bojo desse imaginário, tem fornecido importante material para se pensar sobre essas questões. Os escritores Bernardo Carvalho e Milton Hatoum são expoentes da literatura brasileira e latino-americana desde o final do século passado e com larga e reconhecida produção nos últimos anos; o primeiro, carioca de nascimento, o segundo manauara, ambos escolheram viver em São Paulo e a partir dessa megalópole criam sua ficção que, a nosso ver, abarca o imaginário e as questões do tempo em que estão inseridos. Nessa parte nos propomos a analisar alguns elementos de dois de seus romances. De Hatoum escolhemos Relato de um certo oriente, lançado em 1989; e de Carvalho, O sol se põe em São Paulo, lançado em 2007.

Os dois romances se inserem no que Cury (2007: 9) chama de uma literatura contemporânea brasileira que "tem suas raízes no solo urbano", em que a cidade transforma-se em personagem fundamental, "uma cidade muitas vezes desgastada, cujo tecido social encontra-se rompido", metáfora da impossibilidade de constituição identitária em termos de fixidez, em que "o espaço da cidade assume feição performática, exibido em cenas rápidas, sketches que rompem com formas enunciativas consagradas, deslocando técnicas e gêneros narrativos, sob o olhar de narradores também eles condenados ao seu movimento vertiginoso."

Em Relatos de um certo Oriente, a narradora, neta de migrantes libaneses, cujo nome não é pronunciado, volta para Manaus após vinte anos morando no sudeste - São Paulo, muito provavelmente. Se escrever "é recordar, mas também recriar memória" (HATOUM, apud CASTELLO, 1998), a narradora, com uma identidade esfacelada, nessa viagem de retorno para o lugar onde viveu sua infância e adolescência, vem em busca de uma possível reconstrução de si, via resgate no presente de uma memória sua e dos seus, transformadas em relatos. A pretexto de escrever a seu irmão, que está em Barcelona, e comunicá-lo da morte de Emilie, a matriarca da família, força e presença demarcatória, aquela que comandava a casa, as reuniões, as festas com sua figura forte e sua voz onipresente, a narradora sem nome organiza um extenso relato, que nada mais é do que uma tentativa de juntar os pedaços de uma identidade disforme. O romance é construído sob um entrelaçamento de vozes narrativas. Ela própria abre o relato, passa a vez/voz para seu tio Hakim, em seguida para o fotógrafo alemão Dorner, depois passa 


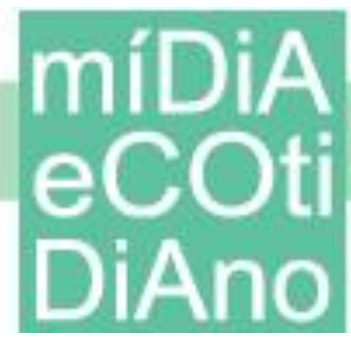

para o pai-avô libanês, sempre fazendo o papel de fomentar que essas vozes falem e ir costurando essas falas, dando a elas um certo ordenamento, para ao final retomar a palavra e fechar o relato. O resgate dessas memórias e dessas vozes se apresenta a ela como possibilidade para reconstruir-se, situar-se em algum lugar, que parece ser o lugar nenhum, ou então, o lugar que somente a linguagem pode dar. O exercício narrativo é buscado como maneira de situar-se, de tentar delinear-se, mesmo que esse delineamento permaneça difuso e móvel, sempre deslocável.

Em O Sol de põe em São Paulo, Carvalho apresenta também um narrador sem nome, como sinal da crise identitária que esse sujeito, descendente de japoneses, exestudante de Letras, publicitário falido, recém separado, passa. Esse sujeito, que se sente deslocado na cidade onde nasceu e que renega toda a tradição japonesa de seus ancestrais, vai, no decorrer do romance, pelo resgate da memória e pela narrativa, tentando, no processo, compor uma identidade minimamente coerente, a partir dos entrecruzamentos com pessoas, seus relatos, seus deslocamentos, suas memórias e narrativas. A dona de bar no bairro Liberdade em que costuma frequentar, migrante japonesa, que se apresenta a ele como Setsuko, o convoca para escrever um romance a partir das memórias que ela vai lhe relatar. Assim como ela cria uma personagem para si mesma, pois na verdade se chamava Michiyo, também cria uma personagem para o narrador, o de escritor, papel que ele assume ao final do romance, mesmo que não queira reconhecer:

\footnotetext{
O que Michiyo me propôs foi um aprendizado e um desafio. Deve ter reconhecido em mim a insatisfação que também a fez correr até onde o sol se põe quando devia nascer e nasce quando devia se pôr, para revelar tempos sombrios (CARVALHO, 2007: 163).
}

Em um jogo imaginativo, mesclando enganos e equívocos, falas e silenciamentos, Setsuko o enreda em sua história, uma trama que envolve um triângulo amoroso, trocas de identidade, vinganças e mortes, que começa no Japão e tem seu fim em terras brasileiras. Ela o faz deslocar-se para o Japão por ele renegado, terra de seus antepassados, cujo acesso até então tinha se dado via relatos de uma nação imaginada e recriada pelos seus parentes que dela tinham saído na condição de migrantes em busca de melhores condições de vida. Esse deslocamento do narrador rumo ao país do sol 
nascente se dá inicialmente pela imaginação de Michiyo, e depois quando Michiyo some, ele se vê na obrigação de dar um fim ao relato, partindo para o Japão para tecer as partes da trama ainda incompletas. Só lhe restava retornar para onde nunca tinha ido, e nesse deslocamento em direção à terra de seus ancestrais repensa sua condição identitária e também se reconstrói. Ao chegar ao desenlace da trama, sintetiza sua trajetória de forma precisa:

Deve ter reconhecido o desacordo em mim. Quis me tornar um escritor, o que não sou. E me fazer escrever na frente de batalha, 'onde a civilização encontra a barbárie e deixa entrever o que dela traz em si', nesta cidade que não pode ser o que é, uma história de homens e mulheres tentando se fazer passar por outros para cumprir a promessa do que são: um ator a quem proíbem atuar; um homem que precisa deixar de ser quem é para lutar pelo país que o rejeita; outro que já não pode viver com o próprio nome, pois morreu numa guerra de que não participou; uma mulher que só ama quando não podem amá-la; um escritor que só pode ser enquanto não for. Uma história de párias, como eu e os meus, gente que não pode pertencer ao lugar onde está, onde quer que esteja, e sonha com outro lugar, que só pode existir na imaginação em nome da qual ela me contou uma história que pergunta sem parar a quem a ouve como é possível ser outra coisa além de si mesmo. (Id., ibid.)

Em ambos os romances distintas vozes se interpenetram, diferentes sujeitos cindidos se deslocam e se entrecruzam por espaços e tempos reconstruídos constantemente pela narrativa memorialística. São escritos romanescos que, como afirma Cury (2007: 11), colocam “ênfase nos mecanismos da memória, tingidas por interpretações da história do país, pondo em relevo estratégias ficcionais de recuperação da memória coletiva e histórica, mas também da pessoal, em que se mesclam o local e o nacional, o particular e o universal, não como memórias essencialistas ou lineares."

Outro aspecto relevante a ser destacado tanto no romance de Hatoum quanto no de Carvalho são as cidades como elementos fundamentais, como personagens em que esses sujeitos cindidos em busca de respostas transitam, se perdem e buscam se (re)encontrar. Cidades-mundo em que distintas culturas se hibridizam, se entrechocam e se refazem nesses contatos; cidades-mundo que abarcam uma diversidade de nações sempre imaginadas pelos nativos ou pelos muitos migrantes e que são constantemente recriadas pela memória e pela narrativa. 


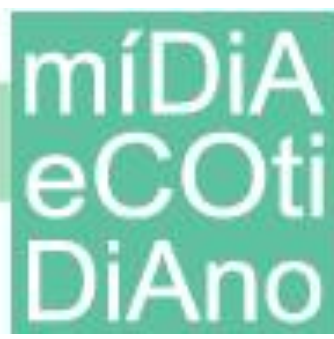

Em Relatos, Manaus é apresentada como uma cidade-mundo em que se condensam, hibridam e disseminam identidades, nações, crenças religiosas, costumes e culturas; uma cidade incrustada entre o rio e a floresta, constrói-se envolta pela diversidade. Cidade-porto que acolhe desde o nativo curandeiro vindo da floresta amazônica ao médico de formação inglesa, os irmãos sicilianos, a criada Anastácia, o tio libanês, os mulçumanos e os católicos maronitas, o português, o francês e o libanês, povoada de muitas e distintas vozes, tempos e espaços múltiplos.

Em $O$ sol se põe, São Paulo, Tóquio e Osaka são as megalópoles nas quais os personagens vivem, circulam, se deslocam, e se sentem estrangeiros em sua própria terra, ou de fato o são, vindos de outros recantos longínquos. O próprio Bernardo Carvalho (apud RESENDE, 2007) em entrevista ajuda a elucidar isso:

\begin{abstract}
Para mim, é fundamental o sentimento de não pertencer a um lugar, um certo deslocamento que impossibilita a integração e o reconhecimento, permitindo ao mesmo tempo que você siga vendo as coisas de fora. Quando vim para São Paulo a cidade funcionou um pouco dessa maneira como terra estrangeira dentro do Brasil. Isso foi muito importante para eu conseguir fazer as minhas coisas, para conseguir escrever. A distância faz você enxergar melhor.
\end{abstract}

Essas cidades-mundo que são lugares, pois apropriadas a seu modo pelos seus moradores, migrantes, turistas, passantes, que a elas atribuem sentido e valor; mas também são constituídas por vários e muitos lugares, territórios dentro da cidade disputados, criados e recriados pelos distintos sujeitos e grupos que nela vivem. Apropriação sempre parcial, porque também esses lugares/territórios estão sempre em processo, transformando e sendo transformados pelos sujeitos que neles vivem ou por eles transitam, em uma via (ou seriam muitas vias) de mão dupla, pois esses sujeitos também, no contato com essas cidades, em que se perdem para se (re)encontrar, transformam-se e as transformam. Esses lugares-mundo, cujas fronteiras, se não somente geográficas, mas também imaginadas, são constantemente deslocadas, criadas e recriadas nas relações, nos embates e nas negociações. Cidades-mundo palcos de uma disseminação de vozes, culturas, costumes, local em que a diversidade de sujeitos se encontram, dialogam, entram em conflito, criam e recriam suas identidades. 


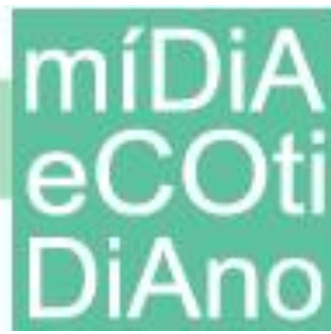

\section{Algumas considerações finais}

O que aqui nos propomos foi, a partir da análise de textos literários latinoamericanos contemporâneos, refletirmos sobre as conexões existentes entre identidade, memória, narrativas e territorialidades. Pensamos esses textos literários, em termos propostos por Williams (2005), como práticas culturais, inseridos dentro de uma cultura - pois é nela que essas práticas se concretizam -, percebida enquanto todo um modo de vida e como um campo de luta em que se disputam os sentidos e os significados sociais. As narrativas propostas por Allende, Faustini, Carvalho e Hatoum como criações contemporâneas situadas no tempo e no espaço nos auxiliam a melhor entender esse mesmo tempo e espaço em que vivemos. Eles nos conduzem a refletir sobre as invenções/criações pela narrativa, pela imaginação e pela memória de uma nação, de uma cidade e das cidades-mundo. Espaços transformados em territórios, dentro de uma perspectiva relacional, gerando territorialidades construídas histórico-socialmente, acarretando tanto uma apropriação simbólica/cultural (em seu sentido mais imaterial), quanto um "domínio" político/econômico (com traços mais propriamente materiais), de um espaço socialmente partilhado, o que acarreta em constante luta política pelo significar social. Os territórios daí resultantes moldam identidades e são moldados por elas.

Em um contexto de globalização e processos correlatos, em que existem múltiplas e muitas vezes sobrepostas territorialidades, é fundamental resgatar que territórios pressupõem tanto lugares/enraizamento quanto fluxos/itinerários, em um processo de embate/negociação constantes, em que redes são construídas, permitindo a rearticulação, o deslocamento e a recomposição das fronteiras desses territórios, interferindo diretamente na construção identitária desses agentes.

\section{Referências}

ALLENDE, Isabel. Meu país inventado. Rio de Janeiro: Bertrand Brasil, 2003.

APPADURAI, A. La modernidade desbordada. Montevidéu, Buenos Aires: Trilce, Fondo de Cultura Económica de Argentina, 2001.

AUGÉ, M. Não lugares: introdução a uma antropologia da supermodernidade. Campinas: Papirus, 2012. 
BHABHA, H. O local da cultura. Belo Horizonte: UFMG, 1998.

BOURDIEU, P. "A identidade e a representação. Elementos para uma reflexão crítica sobre a ideia de região". In: O Poder Simbólico. Lisboa, Difel, 1989.

A miséria do mundo. Petrópolis: Vozes, 2007.

BRIGGS, Asa. "The Sense of Place". In: The Collected Essays of Asa Briggs. Great Britain, The Harverster Press, 1985.

CANCLINI, N. Culturas híbridas. São Paulo: Edusp, 1998.

CARVALHO, Bernardo. O sol se põe em São Paulo. São Paulo: Cia das Letras, 2007.

CASTELLO, José. "Milton Hatoum reclama a volta da indignação". Estado de São Paulo, 14 nov.1998, Caderno 2.

CERTEAU, M. A Invenção do Cotidiano. Petrópolis: Vozes, 1998.

CONY, C.H. Quase memória. Quase-romance. São Paulo: Saraiva:1995.

CURY, M.Z. "Novas geografias narrativas". Letras Hoje. Porto Alegre, v.42, n.4, p.7-17, dez.2007.

FAUSTINI, M. Guia afetivo da periferia. Rio de Janeiro: Aeroplano, 2009.

HAESBAERT e LIMONAD. "O território em tempos de globalização". IN: Revista Etc. No 2 (4), vol.1. Agosto de 2007.

HAESBAERT, R. "Dos múltiplos territórios à multiterritorialidade". Conferência, setembro de 2004.

HALBWACHS, M. A Memória Coletiva. São Paulo: Vértice, 1990.

Les Cadres Sociaux de la Mémoire. Paris: Albin Michel, 1994.

HALL, S. “A Centralidade da Cultura”, Revista \& Realidade, pp.15-46, jul./dez.1997

HATOUM, Milton. Relato de um certo oriente. São Paulo: Cia das Letras, 1989.

MONSIVAIS, C. "Del rancho al Internet." In: SPIELMANN, Ellen (org.). Las relaciones culturales entre América Latina y Estados Unidos después de la guerra fria. Berlin: Wissenschaftlicher Verlag: 2000. p.33-78.

NORA, Pierre. Les lieux de Mémoire. Paris, Gallimard, 1984.

POLLACK, M. "Memória e identidade social”. In: Estudos Históricos, 5 (10). Rio de Janeiro, 1992.

RESENDE, Beatriz. "Entrevista com Bernardo Carvalho", Revista Z, abril 2007. http://revistazcultural.pacc.ufrj.br/entrevista-com-bernardo-carvalho/

RICOEUR, P. Tempo e narrativa. Campinas: Papirus, 1994.

SILVA, Tomaz Tadeu. "A produção social da identidade e da diferença". IN: (org.). Identidade e diferença. Petrópolis, Vozes, 2000, pp. 73-102.

SOUZA, Marcelo Lopes. "O território: sobre espaço e poder, autonomia e desenvolvimento". In: CASTRO, GOMES e CORREAA (orgs.). Geografia: conceitos e temas. Rio de Janeiro: Bertrand Brasil, 1995. 


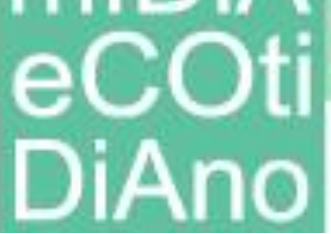

VELHO, Gilberto. Projeto e Metamorfose: Antropologia das sociedades complexas. Rio de Janeiro: Zahar, 1994.

WILLIAMS, R. "Base e superestrutura na teoria cultural marxista". Revista USP, São Paulo, n.65, p. 210-224, março/maio 2005.de Janeiro: IBGE, 1993. 